\title{
Heparin-binding EGF-like Growth Factor, HB-EGF
}

東山繁樹*

\section{I. 発見と钅の後の経過}

ヘパリン結合型 EGF 様増殖因子 (heparin-binding EGF-like growth factor: HB-EGF) は, ヒト末梢血より単 離・培養したマクロファージが産生・分泌する血管平滑筋 細胞の増殖因子として，われわれが最初に同定した増殖因 子である1).その後の蛋白質および cDNA レベルでの構造 解析の結果, HB-EGF は 3 つのジスルフィド結合によって 構成される上皮増殖因子 (EGF) 様構造をもつことが明ら かとなり, EGF ファミリーのメンバーに加わった ${ }^{1,2)}$. HB$\mathrm{EGF}$ は他の $\mathrm{EGF}$ ファミリーメンバーと同様に細胞膜貫 通型の前駆体として合成され，プロセッシングをうけて分 泌型 HB-EGF となる。

1992 年，ジフテリア毒素レセプター (DTR)の遺伝子が クローニングされ，予測される蛋白質が HB-EGF 前駆体と まったく同一であったことから, 膜貫通型 HB-EGF (proHB-EGF) がジフテリア毒素レセプターとして機能す ることが示唆され, 事実,ジフテリア毒素が proHB-EGF を 介して細胞内に進入することが確認されている³.

\section{II. 蛋白質の構造}

HB-EGF は 208 個のアミノ酸残基からなる膜貫通型の 分子構造をもつ. 分子全体を通じては, EGF, TGF- $\alpha$ およ び Amphiregulin と約 35\%前後の相同性を有している. EGFドメインは Her4のリガンドである NDF/heregulin/ GGF と相同性がもっとも高く, 約 50\%におよぶ. パリン およびへパラン硫酸プロテオグリカンの結合部位は, 前駆 体分子の 93-113 残基に位置する KRKKKGKGLGKKRDPCLRKYK の 21 残基からなる配列である。 また， 75 番 目と 85 番目の $\mathrm{Thr}$ 残基は O-グリコシル化の修飾をうけて いる (Fig. 1). 還元下および非還元下での SDS-PAGEで は, 分泌型 HB-EGF (D $\left.{ }^{63}-\mathrm{P}^{149}\right)$ は 21-22 kDa のバンドとし て現れる.これは HB-EGF の分子構造にみられるへパリン 結合部位が正電荷のクラスターを形成しているためと考え られる.また HB-EGF は，4-5 kDa の糖鎖をもつものと見 積もられている2).

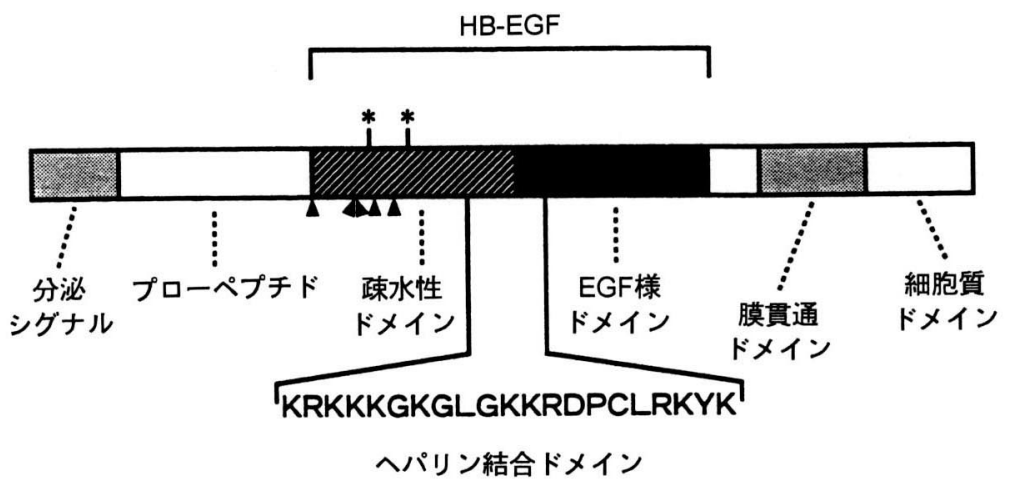

Fig. 1 HB-EGF 前駆体のドメイン構造. ${ }^{*}$ : O-グリコシル化部位, $\Delta$ ：N-末端切断部位.

\footnotetext{
* 大阪大学医学部生化学

原稿受取日：1996 年 2 月 8 日

Shigeki Higashiyama : Department of Biochemistry, Osaka

University Medical School, Osaka, Japan.
} 


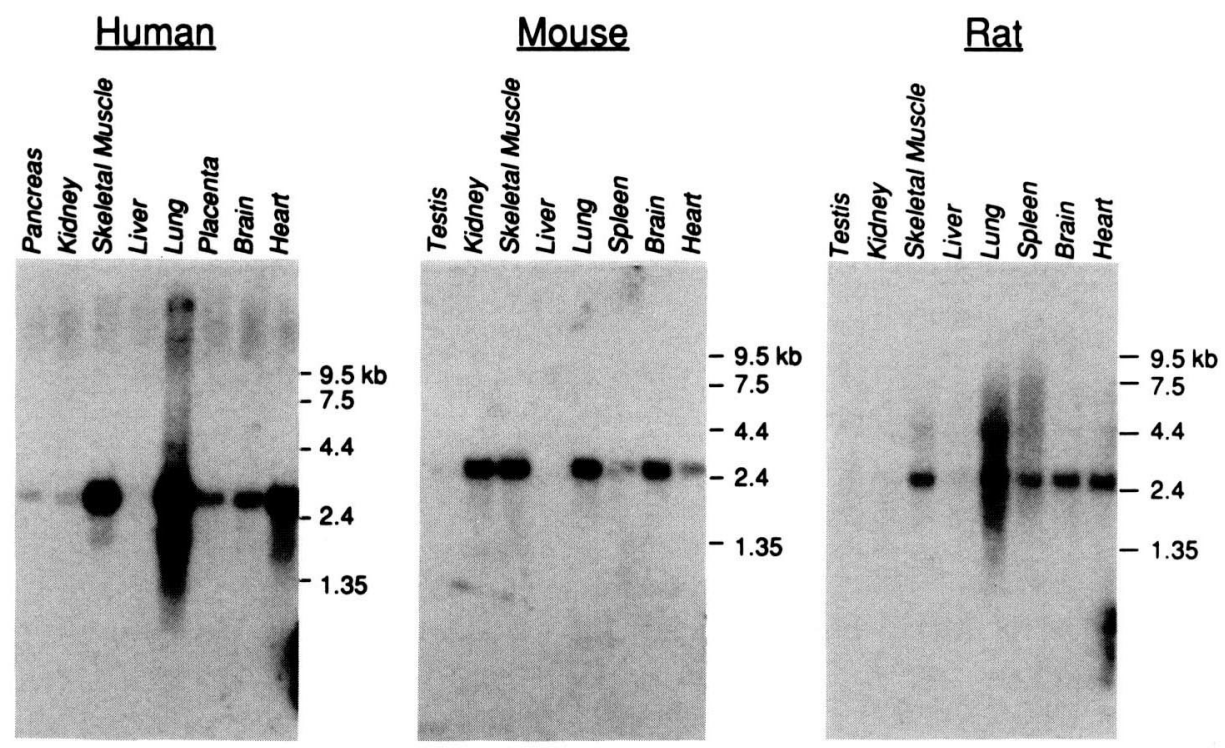

Fig. 2 ヒト，マウスおよびラットの各組織における HB-EGF mRNA の発現.

\section{III. 遺 伝 子}

HB-EGF 遺伝子の cDNA はヒト，サル，マウスおよび ラットでそれぞれ単離され，塩基配列の決定が行われた。 ヒトゲノム遺伝子は，第 5 番染色体にマップされており， 全長が $14 \mathrm{~kb}$ である. mRNA は 6 つのエクソンからコード

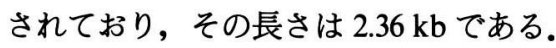

HB-EGFmRNA の発現の組織分布は，ヒト，マウス，お よびラットで調べられている. 図4にみられるように3 種 に共通しているのは, 骨格筋, 肺, 心臟抢よび脳での発現 が高いのに対し，肝臓での発現がきわめて低いことであ る4). ヒトでのこれらの発現パターンは, ジフテリア毒素感 受性とも一致していることから, proHB-EGF の発現が予 測される。

\section{IV. 蛋白質の生理的機能}

HB-EGF は, マウス NIH3T3, ウシ血管平滑筋細胞, ラッ 卜肝細胞およびヒトケラチノサイトの細胞増殖を促進す る. HB-EGF は EGFや TGF- $\alpha$ と同様に, EGFレセプ ター (Herl) に結合して増殖シグナルを送るが, 誘導され る現象には EGF や TGF- $\alpha$ とは異なるものが認められる。 特にウシ血管平滑筋細胞に対して HB-EGF は強力な遊走 因子であるが, EGF や TNF- $\alpha$ にはその活性はほとんど認 められない5．そのメカニズムに関しての詳細は不明であ る.

EGF レセプターへの結合活性は分泌型 HB-EGF のみな らず, proHB-EGF にも認められており, HB-EGF がジャク スタクリン機構 (細胞一細胞接着による増殖刺激) を介し
て増殖因子として機能することが明らかとなっている，た だ，このジャクスタクリン機構による細胞增殖刺激の機構 は, 分泌型 HB-EGFによるものほど単純ではなく, CD9 な どの分子の介在が必要となる ${ }^{6)}$.また, proHB-EGF も分泌

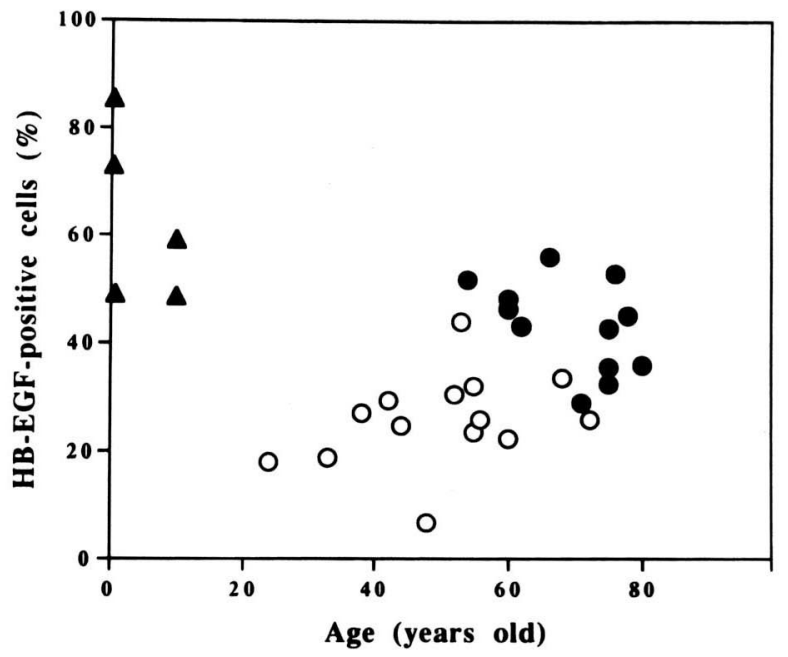

Fig. 3 ヒト動脈中膜平滑筋細胞における HB-EGF 免疫組織活性陽性細胞の年齢および動脈硬化 巣の有無における变化. 乳幼児の中膜平滑筋 細胞では高率に HB-EGF 陽性細胞が認めら れた. HB-EGF 陽性率と, 年齢および動脈硬化 巣の有無についての多变量解析により, 成人 例では加齢により HB-EGF 陽性細胞は有意 に場加すること, および動脈硬化巣が存在す る場合にはさらにその陽性率が増加すること がわかる.・：乳幼児ないし幼小児，○：動脈 硬化巣を有しない成人，○：動脈硬化巣を有 する成人。 
型 HB-EGF 同様に $\mathrm{Q}^{62}$-D ${ }^{63}$ の位置で切断されている.われ われは, 最近, この $\mathrm{N}$ 端切断がエンドプロテアーゼの一つ furin によるものであること, さらに，この切断が proHBEGF のジャクスタクリン活性の発現にきわめて重要であ ることを明らかにしている.

膜貫通型 HB-EGF はジフテリア毒素のレセプターとし て機能するが，われわれがジフテリア毒素の結合部位を解 析した結果，驚くことに EGFドメインであった。しかも， この結合は非常に特異的であり，他の EGF ファミリーの
メンバーには結合しない. また，ジフテリア毒素の無毒性 ミュータントである CRM197 は，分泌型および proHBEGF の両方に結合し，EGFレセプターへの結合を中和す る7). その特異性がきわめて高いことから, 現在, HB-EGF 特異的阻害剂としての CRM197 の有用性を検討中である.

これまでに膜貫通型増殖因子がまったく別の機能分子 として働きうるという報告はなく, HB-EGF がその最初の 分子である。他の膜貫通型増殖因子が，他の毒素やウイル スのレセプターとして機能しているかどうかは非常に興味
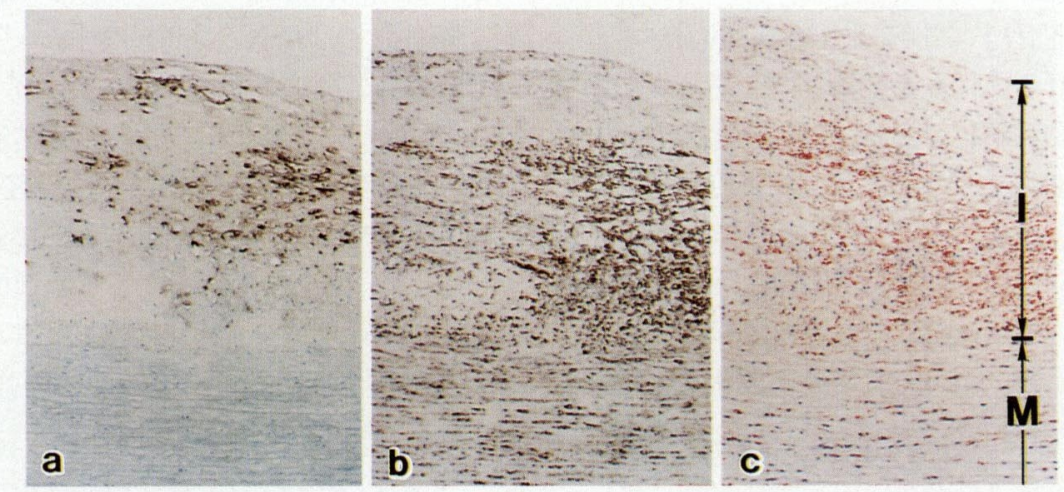

Fig. 4 動脈硬化巣におけるマクロファージ (a)，平滑筋細胞 (b)，および HB-EGF 陽性細胞 (c) の分布. 連続切片で観察すると, HB-EGF 陽性細 (c) はマクロファージ (a) およ び平滑筋細胞 (b) でそのほとんどが構成されていることがわかる.I：intima，M： media, a, b, c : $\times 30$.

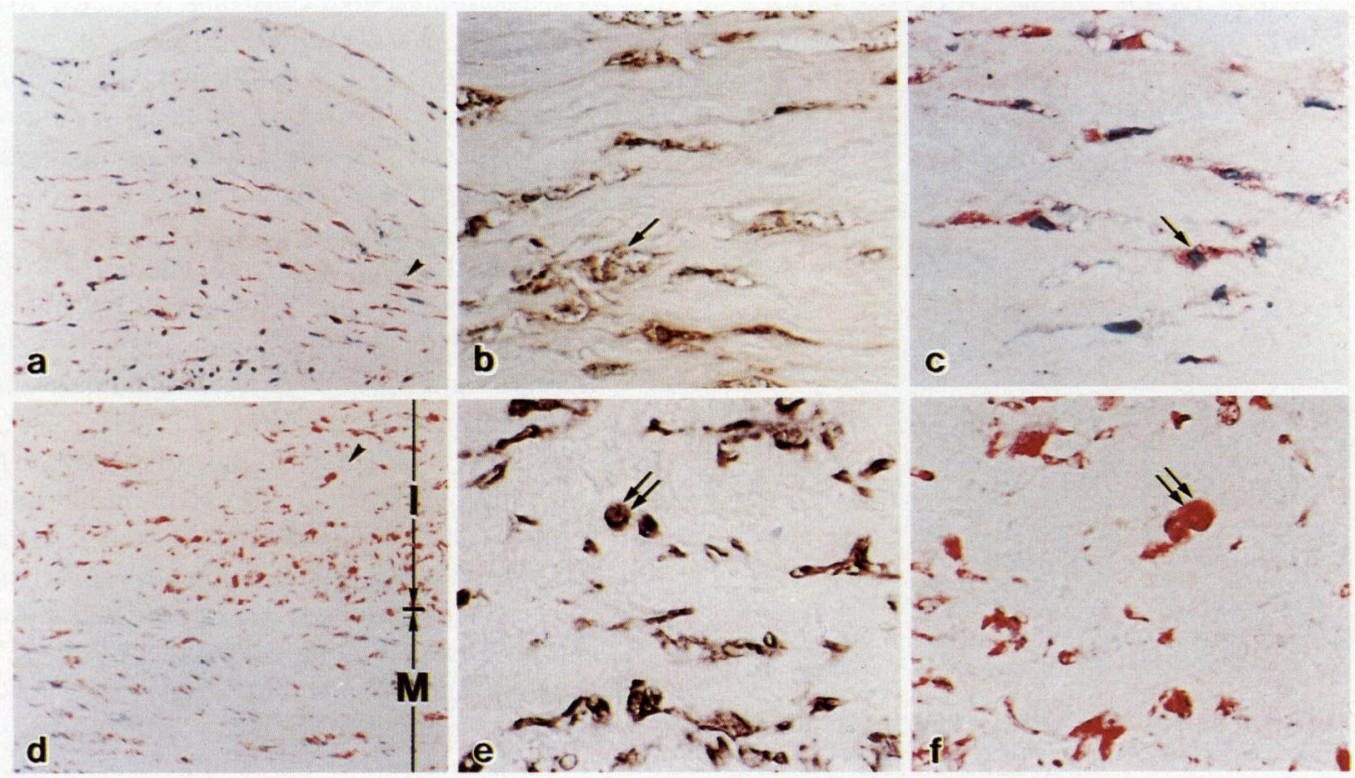

Fig. 5 動脈硬化巣 (プラーク) 内のマクロファージ (b) 抒よび平滑筋細胞 (e) による HBEGF の産生 (a, c, d, f). プラークを含む 2 組のミラー切片における，マクロファージ (b) と HB-EGF (c)，および平滑筋細胞 (e) と HB-EGF (f) の染色体により両細胞が HB-EGF を産生していることがわかる. (a, b, c) 中の矢印および $(\mathrm{d}, \mathrm{e}, \mathrm{f})$ 中の二重矢 印は，それぞれが同じ細胞であることを示す。 a, d : × 120, b, c, e, f : × 350 . 
深い.

\section{HB-EGF の測定}

HB-EGF の定量測定法は現在，まだ確立されていない. 定性測定法については, proHB-EGF がジフテリア毒素受 容体であることを利用して, ジフテリア毒素の感受性で測 定することが可能であり, われわれもこの方法を用いてい る.

\section{VI. 臨床的意義}

HB-EGF と動脈硬化

血管平滑筋細胞の増殖因子である HB-EGF が関与する 疾患としてまず考えられるのは, 平滑筋細胞の遊走と増殖 によってもたらされる動脈硬化である．動脈硬化の発症と 進展を通して関与する細胞群には，血管内皮細胞，マクロ ファージ，血小板， T-細胞そして血管平滑筋細胞がある。こ れまでの解析結果では, これらすべての細胞で HB-EGF の 発現が確認されており，また，標的となる細胞は血管平滑 筋細胞のみであることから, HB-EGF の動脈硬化への関与 はPDGF に匹敵するものであろうと考えられる.また，ヒ

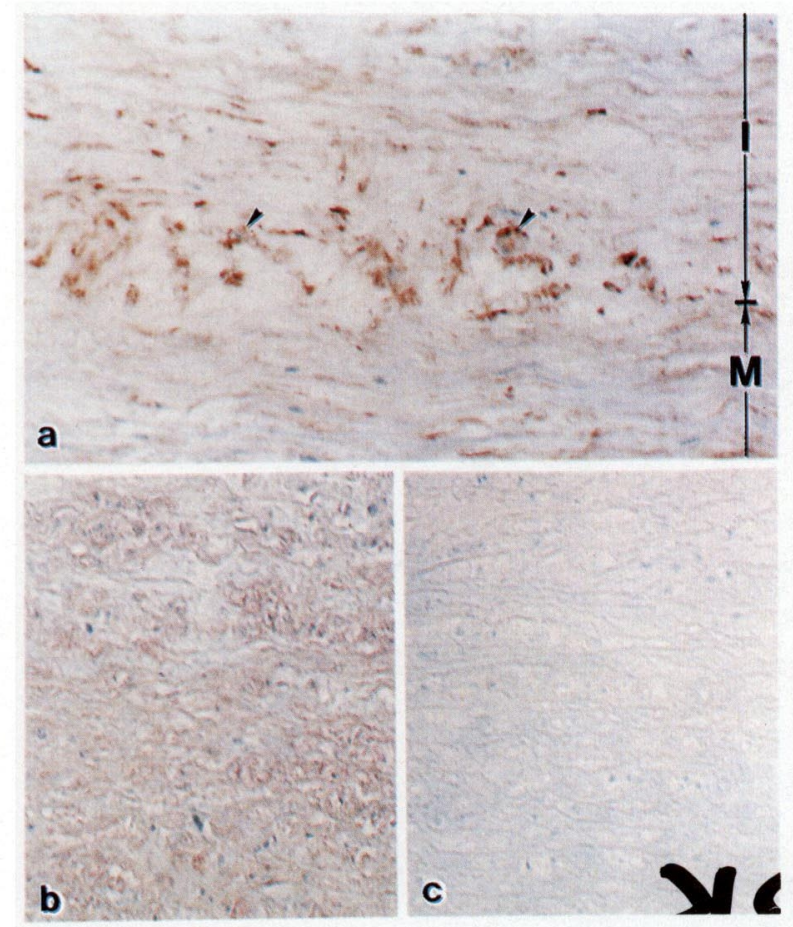

Fig. 6 動脈硬化巣を有する動脈における EGFレセ プター (EGFR) の発現. 硬化巣, 特に中膜側 (中膜直上部) の内膜浸潤平滑筋細胞では, EGFR が強く染色された (a). 中膜平滑筋細 胞では，硬化巣を有しない動脈のそれに比し て強く染色される症例が多かった (b). c : b に対する negative control. (a, b, c) : $\times 200$.
卜動脈壁を抗 HB-EGF 抗体を用いて免疫組織染色を行っ た結果, 中膜平滑筋細胞の HB-EGF 陽性細胞は, 乳幼児で もつとも強く発現しており, 青壮年に至るにつれ陽性細胞 は減少しているが, 中高年ではふたたび増加し, 動脈硬化 巣を有する症例では陽性率がさらに増加する傾向がみられ る (Fig. 1). 内膜においては, 少なくともマクロファージお よび平滑筋で強陽性を示し (Fig. 2, 3), 肥厚とともにその 数は増加し, HB-EGF 陽性細胞は硬化巣においてもっとも 多く観察される (Fig. 1). EGFR は, 中膜平滑筋細胞では 種々の程度の染色性を示し, 動脈硬化巣を有する症例では 陽性細胞が増加しているものが多い.さらに，内膜浸潤平 滑筋細胞ではほとんどの症例において強い発現を認め, HB-EGF と同様の発現パターンを示している (Fig. 4). こ の結果は，動脈硬化でみられる平滑筋細胞の増殖には，平 滑筋細胞自身が HB-EGF を産生分泌し, 自ら作用するオー トクリン機構と平滑筋細胞同士の接着による膜貫通型 HBEGF-EGFレセプターを介する増殖機構であるジャクスタ クリン機構の関与が示唆される.また, 乳幼児ないし幼小 児期の中膜平滑筋にも HB-EGF の強い発現が認められた ことから, 同増殖因子が, 動脈という器官形成およびその 発達に深くかかわつている可能性が示唆される8).

\section{文献}

1) Higashiyama S, Abraham JA, Miller J, Fiddes JC, and Klagsbrun $\mathrm{M}$ : A heparin-binding growth factor secreted by macrophage-like cells that is related to EGF. Science, 251 : 936-939, 1991

2) Higashiyama S, Lau K, Besner G, Abraham JA, and Klagsbrun M: Structure of heparin-binding EGF-like growth factor: Multiple forms, primary structure, and glycosilation of the mature protein. J Biol Chem, 267 : 6205-6212, 1992

3) Iwamoto R, Higashiyama $S$, Mitamura $T$, Taniguchi $N$, Klagsbrun $\mathrm{M}$, and Mekada $\mathrm{E}$ : Membrane protein DRAP 27/CD9 forms a complex with diphtheria toxin receptor and upregulates receptor number and diphtheria toxin sensitivity. EMBO J, 13: 2322-2330, 1994

4) Abraham JA, Damm D, Bajardi A, Miller J, Klagsbrun $\mathrm{M}$, and Ezekowitz $\mathrm{AB}$ : Heparin-binding EGF-like growth factor: Characterization of rat and mouse cDNA clones, protein domain conservation across species, and transcript expression in tissues. Biochem Biophys Res Commun, 190: 125-133, 1993

5) Higashiyama $S$, Abraham JA, and Klagsbrun $M$ : Heparin-binding EGF-like growth factor stimulation of smooth muscle cell migration; Dependence on interactions with cell surface heparan sulfate. J Cell Biol, 122: 933-940, 1993

6) Higashiyama S, Iwamoto R, Goishi K, Raab G, Taniguchi N, Klagsbrun M, and Mekada E: The membrane protein CD9/DRAP27 potentiates the juxtacrine growth 
factor activity of the membrane-anchored heparinbinding EGF-like growth factor (HB-EGF). J Cell Biol, 128 : 929-938, 1995

7) Mitamura $T$, Higashiyama S, Taniguchi N, Klagsbrum M, and Mekada E: Diphtheria toxin binds to the EGF-like domain of human heparin-binding EGF-like growth factor/diphtheria toxin receptor and inhibits specifically its mitogenic activity. J Biol Chem, 270 :
1015-1019, 1995

8) Miyagawa J, Higashiyama S, Kawata S, Inui Y, Tamura S, Yamamoto K, Nishida M, Nakamura T, Yamashita $\mathrm{S}$, Matuzawa $\mathrm{Y}$, and Taniguchi $\mathrm{N}$ : Localization of heparin-binding EGF-like growth factor in the smooth muscle cells and mavrophages of human atherosclerotic plaques. J Clin Invest, 95: 404-411, 1995 